\title{
ENVIRONMENTAL REPORTING ON THE INTERNET BY AMERICA'S TOXIC 100: LEGITIMACY AND SELF-PRESENTATION
}

\author{
Charles H. Cho* \\ Assistant Professor \\ John Molson School of Business \\ Concordia University \\ 1455, de Maisonneuve Blvd. West \\ Montréal, Québec H3G 1M8, Canada \\ Tel: 514-848-2424 ext. 2319 \\ Fax: 514-848-4518 \\ E-mail: ccho@jmsb.concordia.ca
}

\author{
Robin W. Roberts \\ $\mathrm{Al}$ and Nancy Burnett Eminent Scholar and Director \\ Kenneth G. Dixon School of Accounting \\ University of Central Florida \\ 4000 Central Florida Blvd \\ Orlando, FL 32816-1400 \\ Tel: 407-823-6726 \\ Fax: 407-823-3881 \\ E-mail: rroberts@,bus.ucf.edu
}

* Corresponding author

Please do not quote, cite, distribute or copy without the consent of the author.

December 2007 


\title{
ENVIRONMENTAL REPORTING ON THE INTERNET BY AMERICA'S TOXIC 100: LEGITIMACY AND SELF-PRESENTATION
}

\begin{abstract}
This study uses Goffman's self-presentation theory to examine corporate website environmental disclosures from an organizational legitimacy perspective. We argue that corporations use Internet environmental disclosure to project a more socially acceptable environmental management approach to public stakeholders. We argue further that this disclosure activity is often de-coupled from their actual environmental performance. To test these conjectures, we refine and employ a comprehensive disclosure evaluation metric to assess both the content and the presentation of these types of disclosures and utilize a firm's America's Toxic 100 toxic score - a newly developed measure based on the US Environmental Protection Agency's toxics release inventory (TRI) data, to proxy for environmental performance. Based on empirical tests of four size-matched samples, our findings support our conjectures, showing that worse environmental performers provide more extensive disclosure in terms of content and website presentation.
\end{abstract}

Keywords: Website environmental disclosure; legitimacy, self-presentation; Goffman 


\section{ENVIRONMENTAL REPORTING ON THE INTERNET BY AMERICA'S TOXIC 100: LEGITIMACY AND SELF-PRESENTATION}

\section{Introduction}

The latter years of the Twentieth Century witnessed a number of environmental catastrophes (e.g., the 1979 Three Mile Island and 1986 Chernobyl nuclear power plant accidents, the 1984 Bhopal Union Carbide poisonous gas leak, and the 1989 Exxon Valdez and 1999 Erika oil spills) that triggered a visible shift of public concern toward environmental issues and corporate environmental performance (Smith, 2000). These incidents placed significant pressure on companies whose operations inherently harm the natural environment. Wolf (1996) notes, for example, that the Bhopal accident led the U.S. Congress to pass the Emergency Planning and Community Right-to-Know Act of 1986 (hereafter, "EPCRA"), in an attempt "to alleviate the lack of comprehensive emergency response planning and the scarcity of information on dangerous chemical releases around the nation" (p. 219). A major component of the EPCRA was the Toxic Release Inventory (TRI) program, which requires facilities operating in certain industries ${ }^{1}$ to annually disclose information related to the release of hazardous chemicals. The TRI database captures and makes available to the public information about the emission levels of certain toxic chemicals (Environmental Protection Agency, 2004).

Parallel to these developments, Internet access has grown tremendously with the estimated number of Internet users worldwide passing the billion threshold during 2005 (Internet World Stats, 2006). The explosive growth of the Internet provides companies the opportunity to "disseminate information to a very wide audience of shareholders, potential investors, and other constituents economically, quickly, and in an undiluted fashion" (Antin and Haas, 2001, p. 21). Companies seem to enjoy primarily its less restrictive space, which allows them to (1) make available a broad and deep range of information, (2) make information accessible 24 hours a day from any online computer

\footnotetext{
${ }^{1}$ The TRI reporting requirement applies to facilities with 10 or more full-time employees that manufacture (including importing) or process more than $25,000 \mathrm{lbs} /$ year, or otherwise use over 10,000 lbs/year of a listed chemical, and that are in one of the following sectors: manufacturing, metal mining, coal mining, electrical utilities that combust coal and/or oil, Resource Conservation and Recovery Act (RCRA) Subtitle $\mathrm{C}$ hazardous waste treatment and disposal facilities, chemical and allied products wholesale distributors, petroleum bulk plants and terminals and solvent recovery services (Environmental Protection Agency, 2006).
} 
terminal anywhere in the world, and (3) reach an audience of millions within seconds (Jones et al., 1999). Perhaps not surprisingly, the dissemination of environmental information and reports on Internet corporate websites has become increasingly popular (Jones et al., 1998, 1999; SustainAbility/UNEP, 1999).

SustainAbility/United Nations Environment Program's (SustainAbility/UNEP) Internet Reporting Report (1999, p. 18) notes the potential value of Internet-based disclosure. The group claims:

The Internet will provide both new (increasingly 'wireless') channels for existing forms of corporate accountability and help evolve new forms of accountability and corporate governance. Imagine, for example, that a company's stakeholders had access not only to online data on how it was performing against key sustainability-related targets, but also to instantaneous benchmark results, showing how it measures up against its competitors - and where areas of risk might be.

However, Patten and Crampton (2004) suggest this vision may be overly optimistic based on the growing evidence that, similar to financial report environmental disclosure, Internet environmental disclosure seems to serve more as a legitimation device than as an effort at greater corporate accountability.

The purpose of this study is to extend organizational legitimacy arguments by examining the content and presentation of corporate website environmental disclosure in relation to firm environmental performance. Firm environmental performance is captured by firm toxic score, a relatively new but more relevant measure based on the TRI data and provided by the Political Economy Research Institute (PERI) at the University of Massachusetts at Amherst. The toxic score is measured by taking into account both the toxicity of specific chemicals and the population exposure in relation to their release location. The PERI aggregates the U.S. Environmental Protection Agency's (EPA) TRI data from the facility level to a parent company level, ranks those firms by toxic score, and publishes the list of the top 100 (i.e., America's Toxic 100) on their own website. The assessment of both the content and the presentation of Internet website environmental disclosure is performed by a comprehensive disclosure evaluation metric that we develop based on the works of Jones et al. (1998), Marston and Polei (2004) and Patten and Crampton (2004). More importantly, we situate Goffman’s (1959) 
sociological theory of self-presentation within the organizational legitimacy framework and apply it to obtain a better understanding of the online environmental reporting motivations and practices of US corporations.

This paper makes contributions to social and environmental accounting research by refining the measures for environmental disclosure on the Internet and utilizing a newly developed measure of environmental performance. Prior research indicates consistency, reliability and validity issues in the measurement of social and environmental disclosures (see, e.g., Milne and Adler, 1999; Unerman, 2000) and environmental performance (see, e.g., Ingram and Frazier, 1980; Hughes et al., 2001; Patten, 2002a). While we do not claim to overcome those issues in the present study, we introduce new variable measurements and empirically test them here.

The remainder of the paper proceeds as follows. The next section provides background information and a literature review on Internet environmental reporting. The theoretical frameworks and hypotheses are developed in section 3, and section 4 provides the research methods and discussion on how the analysis is performed. We analyze and present the results in the subsequent section. Finally, a discussion, with limitations and future research opportunities are presented in section 5 .

\section{Background and prior research}

The exponential growth of Internet usage has enabled companies to establish a flexible, reliable, effective (Jones et al., 1998; Shepherd et al., 2001) strategic (Wheeler and Elkington, 2001) medium to communicate with stakeholders and relevant publics (see Roberts, 1992; Neu et al., 1998). One of the Internet tools is the World Wide Web and its popularity has increased over the last two decades because the corporate website is viewed as "a dynamic and evolving medium" (Ettredge et al. , 2001, p. 150), making company information available to a large audience. Internet websites also may satisfy the demand for quality, timely and easy to obtain information (Foy, 1996) and allow audio/video files, animated graphics and 3D simulations to be connected via hyperlinks (Jones et al., 1998). Corporate website designers utilize these features to exploit the full capabilities of the medium, but also because corporate websites need to provide the ability to access, navigate, and search information from documents that "accommodate 
hypertext linking, graphics, multimedia, linking to external URLs from within the document, and complex searches" (Rauch et al., 1997).

Growth in the usage of corporate websites has led to the emergence of a research literature stream focusing on Internet financial reporting ${ }^{2}$ (IFR). For example, studies have examined IFR in countries including the US (see, e.g., Ashbaugh et al., 1999; Ettredge et al., 2001; Patten, 2002b), Germany (see, e.g., Marston and Polei, 2004), Spain (see, e.g., Gowthorpe and Amat, 1999), and Sweden (see, e.g., Hedlin, 1999), as well as in companies across different countries (see, e.g., Flynn and Gowthorpe, 1997; Debreceny et al., 2002).

Similarly, there has been a growing interest in corporate social responsibility reporting (including environmental reporting) on the Internet. The issue of satisfying stakeholders' demands for the dissemination of relevant information through different types of communication media has also been investigated.

Zeghal and Ahmed (1990) argued that assessing the scope of corporate social reporting solely on the basis of annual reports is misleading and that managers should perceive the mass media as a more appropriate means of communicating social information. Their results indicated that (1) the informational content and the format of social information disclosure (quantitative, narrative, monetary) were related to the company's operations, and (2) this content was distributed by a medium of communication in a format that was geared toward the target audience.

Azzone et al. (1997) identified eight core company stakeholder groups (academia, employees, environmental NGOs, financial community, local community, regulators and policymakers, shareholders, and trade and industry) and analyzed each of their content requirements and preferred media to receive environmental information. Jones et al. (1998) specified that each of these requirements can be met by using Internet tools such as creating hyperlinks between relevant sections from previous years' reports.

\footnotetext{
${ }^{2}$ In general, the potential benefits of IFR, as noted by Ashbaugh et al. (1999), include (1) reduced costs in the dissemination or gathering of information, (2) the ability to communicate with previously unidentified consumers, and (3) the ability to provide more timely financial information to stakeholders.
} 
SustainAbility/UNEP (1999) prepared and published the Internet Reporting Report. It proposed a five-stage model of corporate environmental reporting ${ }^{3}$, an important benchmark to evaluate environmental reporting. The model primarily focused on the importance of Internet usage to reach stages 4 and 5, which are "state-of-the-art reporting" and "sustainable reporting", respectively. Survey results indicated that $55 \%$ of 150 leading companies provided some form of environmental communication on their Internet websites, while $49 \%$ of the sites offered feedback forms to users. The report also noted that the Internet became a medium for increasing corporate social and environmental accountability. The five-stage reporting model is depicted in Appendix A.

Williams and Pei (1999) examined the corporate social disclosures on websites and in annual reports of 172 companies from Australia, Singapore, Malaysia and Hong Kong. They found that companies in Australia appeared to provide more corporate social disclosures on their Internet websites than in their annual reports. In Malaysia, the amount of information was found to be almost at the same level in both media, whereas in Hong Kong, websites were utilized less as a medium of social disclosure ${ }^{4}$. Therefore, the country of origin appeared to be a differentiating factor when comparing the utilization of Internet websites vis-à-vis the annual reports.

Isenmann and Lenz (2000) use four headings to classify the benefits of using Internet corporate environmental reports. They are (1) environmental report publication purposes, (2) environmental reporting process, (3) environmental report contents, and (4) environmental report design. In general, the benefits regarding the reporting process are attributed to a company's perspective, while those concerning the contents and the design are of users' interests, and the purposes of environmental report publication may be related to both the company and the users.

Surprisingly, few studies have investigated the motivations for companies to present social and environmental information on their websites. Jones et al. (1999) examined 275 corporations that had previously published hard copy environmental

\footnotetext{
${ }^{3}$ The advantages of environmental reporting on Internet websites were identified as global reach, immediacy, updatability, transparency, linkability and interactivity.

${ }^{4}$ This is somewhat consistent with the SustainAbility/UNEP report, which indicated that in Asia, the main stakeholder group targeted was "customers" and environmental disclosure was non-existent or inadequate. As such, it was noted that the reporting in Asia appeared to be lagging behind Western standards.
} 
reports (the sample was drawn from 21 countries across 21 different industries). They found that "a total of $41 \%$ of the companies provided little or no environmental information on their website" $(1999$, p. 77). It was noted that companies were still at an infancy stage to exploit the full potential of Internet-based environmental reporting. For example, the Internet environmental reporting practices of multinational companies showed a lack of familiarity with the global nature the Internet, foregoing the opportunity to facilitate communication of their activities in developing countries to those countries' stakeholders 5 .

Esrock and Leichty (1998) examined disclosures across 13 different social responsibility areas on Fortune 500 companies' websites and found that corporations used a variety of tools for social disclosure. However, they concluded that despite their flexibility, websites have been used primarily to disseminate social disclosures similar to the traditional, one-way "top-down/information-push" communication.

Finally and more recently, Patten and Crampton (2004) investigated (1) whether the Internet was in fact being used to further environmental communication with stakeholders and (2) whether website environmental disclosure, like financial report environmental disclosure, was merely "a function of corporate attempts at legitimation." Based on their analysis, Patten and Crampton (2004) suggest that SustainAbility/UNEP's views of the Internet as a medium for higher corporate social and environmental accountability may be "overly optimistic" and that the focus of website environmental disclosure appeared to be another tool used to legitimate the corporation rather than adding to accountability.

\section{Theoretical framework and hypotheses development}

\section{Legitimacy and Goffman's theory of self-presentation}

In general, legitimacy theory suggests that social disclosure is a direct function of social and/or political pressure faced by organizations (i.e., firms under higher pressure

\footnotetext{
${ }^{5}$ Based on this, it might be speculated that there is a chance that technology can transform or at least reveal the global social responsibilities of multinationals and possibly pressure them to upgrade their disclosure in developing countries, if, in fact, the reporting is not at the same level.
} 
will provide a larger amount of social disclosures). More specifically, proponents of the theory (e.g., Lindbolm, 1994; Patten, 1991, 1992, 2002a; Hackston and Milne, 1996) argue that the demand for legitimacy systematically drives the extent of social and environmental disclosures. Dowling and Pfeffer (1975) state "organizations are legitimate to the extent that their activities are congruent with the goals of the superordinate system" (p. 123). As such, one of the strategies organizations can undertake to gain, repair or maintain legitimacy is to use communication to project an image of social legitimacy (Dowling and Pfeffer, 1975, p. 127). Communication thus plays a pivotal role in the legitimation process and this association potentially explains why legitimacy theory has been widely tested, espoused and validated in the social and environmental accounting and disclosure literature (see, e.g., Deegan and Gordon, 1996; Hackston and Milne, 1996; Neu et al., 1998; O’Donovan, 1999; 2002; Patten, 1991; 1992; 1995; 2002a; Deegan, 2002; Deegan et al., 2002; Milne and Patten, 2002). Overall, Gray et al. (1995) argue that the organizational legitimacy framework has been viewed as one of the "most penetrating analyses" of corporate social disclosure (p. 52).

The concept of legitimacy was, however, originally rooted in sociology and social theory literature (see, e.g., Weber, 1966; Dowling and Pfeffer, 1975) ${ }^{6}$. As such, we draw upon sociologist Erving Goffman's theory of self-presentation to make analogies with some features of the organizational legitimacy framework. Brown (1997) suggests that individuals and organizations "possess identities that are preserved through individual and social processes of self-esteem regulation" (p. 643). Therefore, although Goffman (1959) studied the presentation of self primarily at the individual level, his concepts and framework can also be effectively applied to increase our understanding of group and organizational behavior. In fact, Young and Massey (1978) call for analyses at the "macro-analytic levels" (p. 84) and a "dramaturgical direction” (p. 84) of Goffman's work on the presentation of self. In his book The Presentation of Self in Everyday Life, Goffman (1959) employs the metaphor of theatrical performance as a framework.

\footnotetext{
${ }^{6}$ For example, Weber (1966) argues that not only are most forms of power in dire need for legitimacy, but entire political and social systems look for a legitimation process to prevent crises and degeneration. Dowling and Pfeffer (1975) suggest that when a disparity, actual or potential, arises between the values of the society and perception of the values of the company, there is a threat to the legitimacy of the company, labeled as the "legitimacy gap".
} 
Consistent with this notion, we analogize Goffman's "individual" to the organization itself, and the "others" to stakeholders and the relevant publics (see Neu et al., 1998).

Each person in everyday social interaction presents himself and his activity to others, attempts to influence and control the impressions they form of him, and uses certain techniques in order to sustain his performance, just as an actor presents a character to an audience. First, he introduces the notion related to the perception of others on an individual, as follows:

When an individual enters the presence of others, they commonly seek to acquire information about him or to bring into play information about him already possessed. They will be interested in his general socio-economic status, his conception of self, his attitude toward them, his competence, his trustworthiness, etc (...). Information about the individual helps to define the situation, enabling others to know in advance what he will expect of them and what they may expect of him. Informed in these ways, the others will know how best to act in order to call forth a desired response from him (Goffman, 1959, p. 1).

He then takes a view from the individual standpoint, as stated below:

Let us now turn from the others to the point of view of the individual who presents himself before them. He may wish them to think highly of him, or to think that he thinks highly of them, or to perceive how in fact he feels toward them, or to obtain no clear-cut impression (...). Regardless of the particular objective which the individual has in mind and of his motive for having this objective, it will be in his interests to control the conduct of the others, especially their responsive treatment of him. This control is achieved largely by (...) expressing himself in such a way as to give them the kind of impression that will lead them to act voluntarily in accordance with his own plan (Goffman, 1959, p. $3-4)$.

Lastly, he makes a clear distinction between two modes of expression of an individual:

The expressiveness of the individual (and therefore his capacity to give impressions) appears to involve two radically different kinds of sign activity: the expression that he gives, and the expression that he gives off. The first involves verbal symbols or their substitutes which he uses admittedly and solely to convey the information that he and the others are known to attach to these symbols. This is communication in the traditional and narrow sense. The second involves a wide range of action that others can treat as symptomatic of the actor, the expectation being that the action was performed for reasons other than the information conveyed in this way (...). The individual does of course intentionally convey misinformation by means of both of these types of communication, the first involving deceit, the second feigning (Goffman, 1959, p. 2). 
The above quotes can thus be interpreted and applied to the individual-organization and others-society analogies as follows.

Stakeholders and relevant publics are intrinsically concerned about the organization's performance and activities because of their societal expectations and the social contract (see Shocker and Sethi, 1973; Matthews, 1993; Deegan and Rankin, 1996; Deegan, 2002 for more detailed discussion on social contract). Such expectations are complemented by a desire to acquire pertinent information about the organization because it helps to define the situation, enabling the stakeholders and relevant publics to know in advance what the organization will expect of them and what they may expect of the organization. Because the organization's goal is to project a positive image and enhance its reputation, it will undertake certain legitimate-looking activities, but also communicate those activities to its stakeholders and the general public in order to meet those societal expectations and satisfy the public's demands. It will be in the organization's interests to control the responsive treatment and conduct of the stakeholders and relevant publics.

An organization can achieve control by expressing itself in such a way as to give the kind of impression that will lead its stakeholders and relevant publics to act voluntarily in accordance with the organization's own plans. There are two nonexclusive attributes to this communication. First, there is the expression "given." That is, for example, the use of actual verbal narratives and words (i.e., content) solely to convey information (communication in the traditional and narrow sense). The second attribute is the expression "given off" and this includes, for example, the use of nonverbal cues and symbols (i.e., physical presentation) to present information. Drawing from Goffman's work, Young and Massey (1978) suggest that 1) high disparity among organizations drives the need to recognize that "presentations will not be based on parity" (p. 85) and 2) it is in the best interest of profit-oriented organizations to utilize "theatre, social science, and sophisticated communication strategies" (p. 85, emphasis added) to attract public attention, thus producing a perception of legitimate-looking activities. Therefore, it appears that similar traits to organizational legitimacy are inferred from Goffman's pillar concepts of the self-presentation theory. 


\section{Development of hypotheses}

Prior research (see, e.g., Deegan and Gordon, 1996; Hackston and Milne, 1996; Patten, 1992; 2002a) shows that firm size and industry classification both affect the public pressure potentially faced by companies with environmental concerns. These factors can also be significantly related to the extent of environmental disclosure in annual reports or on the Internet. The TRI program of 1986 requires U.S. firms' manufacturing facilities to file annual reports on toxic releases of more than 600 chemicals. The EPA is required to make this information available to the general public ${ }^{7}$. Companies with higher levels of toxic releases may thus be subject to greater public pressure than their better performing counterparts. For example, Wolf (1996) documents that environmental groups have relied on TRI data to generate "reports publicizing the names of the top polluting facilities, industries, chemicals, and states in an effort to invite public and regulatory pressure for toxic substance reductions" (p. 286). Konar and Cohen (1997) note that private parties may use TRI data to bring lawsuits against firms, "green consumers" may boycott companies with high pollution records, and government agencies may use the data for enforcement purposes (e.g., increased penalties and/or cost of new pollution equipment).

Legitimacy theory arguments suggest that exposure to public and regulatory scrutiny inherently drives companies to polish their overall image. The present study refines the measurement of website disclosure content and presentation, and focuses on one social responsibility area, the environment. As such, we compare measurement scores for four size-matched sample groups of companies from environmentally sensitive industries (ESI) versus non-environmentally sensitive industries (non-ESI), and from worse environmental performing firms versus better environmental performing firms.

Accordingly, our first set of hypotheses relates to information content of environmental disclosure. Information content is defined as the extent of the underlying themes or topics that are textually present in the environmental disclosures. In line with the legitimacy framework, we predict higher levels of website environmental disclosure content for worse performing firms (i.e., top-ranked with the highest levels of toxic

\footnotetext{
${ }^{7}$ These disclosures include a list of the amount of toxics released but at a facility-level. The PERI complies this data and aggregates them at a firm-level.
} 
releases) than for better performing firms within both environmentally sensitive and nonenvironmentally sensitive industries. In contrast, because worse environmental performing firms are already subject to much negative exposure merely due to being listed as such, we believe that these firms will have incentives to provide high levels of environmental disclosure content-wise regardless of their industry membership. Therefore, we state our hypotheses as follows:

$\mathrm{H}_{1 \mathrm{a}}$ : Ceteris paribus, for firms from environmentally sensitive industries, the extent of website environmental disclosure content will be higher for worse environmental performers than for better environmental performers.

$\mathrm{H}_{1 \mathrm{~b}}$ : Ceteris paribus, for firms from non- environmentally sensitive industries, the extent of website environmental disclosure content will be higher for worse environmental performers than for better environmental performers.

$\mathrm{H}_{1 \mathrm{c}}$ : Ceteris paribus, for worse environmental performers, the extent of website environmental disclosure content will not differ across the environmental sensitivity of firm industries.

Our second set of hypotheses centers on the presentation of website environmental disclosure. Goffman's (1959) theory on the presentation of self is relevant to this research. The analogy (based on discussion in Section 3.1) can be drawn between (1) the individual's attempt to mislead others by "feigning" and "expressing himself in such a way as to give them the kind of impression that will lead them to act voluntarily in accordance with his own plan" (Goffman, 1959, p. 2-4); and (2) the efforts of a firm with poor environmental performance to manage stakeholders' impressions by a strategic presentation of environmental information on a savvy website.

Isenmann and Lenz (2000) identify presentation style as a relevant domain of the online environmental report design. The information presentation is defined as the extent to which technological, multimedia and interactive functions are used for the enhanced disclosure of environmental information to add dimension to the plain text narratives. 
Negative environmental performance can thus be offset by presentation on a savvier website because the latter would constitute an image-building and legitimating process strategically undertaken by corporations. Therefore, in line with Goffman's (1959) theory of self-presentation, we expect worse environmental performers to exhibit more heightened expressiveness to the presentation of their website environmental disclosures than their better counterparts. However, similar to $\mathrm{H}_{1}$, as worse performing firms are inherently already subject to negative publicity, they also have high incentives to present their environmental disclosures with many technological, multimedia and interactive features, regardless of industry membership ${ }^{8}$. We formally state these hypotheses as follows:

$\mathrm{H}_{2 \mathrm{a}}$ : Ceteris paribus, for firms from environmentally sensitive industries, the extent of website environmental disclosure presentation will be higher for worse environmental performers than for better environmental performers.

$\mathrm{H}_{2 \mathrm{~b}}$ : Ceteris paribus, for firms from non- environmentally sensitive industries, the extent of website environmental disclosure presentation will be higher for worse environmental performers than for better environmental performers.

$\mathrm{H}_{2 \mathrm{c}}$ : Ceteris paribus, for worse environmental performers, the extent of website environmental disclosure presentation will not differ across the environmental sensitivity of firm industries.

\footnotetext{
${ }^{8}$ The expectations stated in both $\mathrm{H}_{1 \mathrm{c}}$ and $\mathrm{H}_{2 \mathrm{c}}$ are in contrast with Cho and Patten (2007). This is presumably due to the nature of the dependent variable measure of environmental disclosure (10-K monetary environmental disclosure versus content and presentation of website environmental disclosure) but also the exposure of the Toxic 100 as opposed to the KLD ratings. Being listed in the Toxic 100 is more visible, which induces all firms to disclose more information on savvier websites regardless of industry membership. In contrast, KLD ratings are less visible, thus monetary disclosure levels may vary across industry type.
} 


\section{Research methods}

\section{Sample selection}

In order to be included in this study, sample firms had to:

1. Be part of the list of firms analyzed by the PERI, which includes Toxic 100 firms and non-Toxic 100 firms ${ }^{9}$.

2. Have an accessible corporate website that contains environmental information $^{10}$.

3. Have financial data available on Compustat.

4. Meet the matching selection criterion below.

We used a dichotomous yes/no coding system to identify firms that operate in ESI from firms that do not. ESI firms are labeled as companies with a primary SIC code of 10xx/14xx (mining), 13xx (oil extraction), 26xx (paper), 28xx (chemical, except pharmaceutical, code 283x), 29xx (petroleum), and 33xx (metals).

Similar to Cho and Patten (2007), we eliminated size effects by constructing four groups of 19 companies $^{11}$ matched on 2005 revenue levels. Group one includes non-ESI, better performing companies; group two includes worse performing companies operating in non-ESI; group three includes better performing firms operating in ESI; group four consists of ESI, worse performing firms. Sample firms ranged in size (based on 2005 revenue levels) from $\$ 1,249.6$ million to $\$ 21,894$ million, with a mean (median) of $\$ 7,651.3$ million $(\$ 6,329.7$ million). T-tests on the differences in mean size across groups showed no statistically significant differences. Table 1 below provides summary data on the sample firms.

\footnotetext{
${ }^{9}$ The PERI provided us with a list of all the firms for which they compiled and aggregated TRI data and computed toxic score at the firm level. There were 338 companies in the original list. The top 100 in terms of toxic score from this list constitutes America's Toxic 100.

${ }^{10}$ Websites were accessed during November 2006. Some sample firms had been merged or acquired and had a newly directed website. Whenever possible, we used a web tool, Waybackmachine (http://archive.org) to retrieve the most recent website version of the sample company for the analysis. In addition, companies with both a zero content and presentation score were labeled as "no environmental information available" and were excluded from the sample because of the inability to analyze them for the purpose of this study.

${ }^{11}$ A total of 19 firms per matched group met all sample criteria, to constitute the final sample of 76 firms.
} 


\section{Description of the dependent variables}

Since the hypotheses require the test of both the content and the presentation of corporate website environmental disclosure, we developed a comprehensive, two-section criteria disclosure evaluation metric to evaluate the 76 corporate websites in the sample. We based the set of criteria on prior research in both environmental and financial reporting on corporate Internet websites. Patten and Crampton (2004) used a 21-item scoring scheme of corporate webpage and annual report environmental disclosures to examine the thematic content and areas of different environmental issues. We use this particular scoring index as a basis for the development of the criteria in terms of the "content" analysis section of the website environmental disclosure. The presentation part of this study's comprehensive 20-item metric was established according to the indexes built by both Jones et al. (1999) and Marston and Polei (2004) but tailored for information related specifically to the environment ${ }^{12}$. Jones et al. (1999) identified several items forming a framework of guidelines that specifically aim at assessing an environmental reporting website, while Marston and Polei (2004) proposed some complementary items related to the presentation of corporate website financial information ${ }^{13}$, focusing on how such information is displayed on corporate websites and "which technological options were used to make the home page user friendly" (Marston and Polei, 2004).

The comprehensive metric thus consists of two sections (i.e., content and presentation) and 41 items in total. There are 21 items in the content section (all items were drawn from Patten and Crampton, 2004) and 20 items in the presentation section (only applicable and relevant items were selected from Jones et al., 1999 and Martson and Polei, 2004). All of the items can be measured on a dichotomous yes/no basis,

\footnotetext{
${ }^{12}$ It must be noted that although some metric items for this section may inherently relate to the entire website, the focus remains on the presentation of environmental disclosure and information on the website, rather than an overall assessment.

${ }^{13}$ Although this study examined the overall website financial reporting practices by German companies, the distinct presentation section of the 53-item scoring checklist provided useful and complementary items that broaden the codification scheme of website presentation in general.
} 
quantified as 1 and 0 , respectively. The metric generates separate scores to evaluate the content and presentation of corporate website environmental disclosure, respectively. Thus, content scores could range from zero ${ }^{14}$ to 21 and presentation scores could vary from zero to 20. Actual website environmental disclosure content scores ranged from zero (one company) to 10 (3 companies), with a mean score of 4.14 , while actual presentation scores ranged from zero ( 3 companies) to 11 ( 2 companies), with a mean score of 4.58. The overall comprehensive evaluation metric, along with the sources for each item, is reproduced in Appendix B. In addition, a list of omitted items from Jones et al. (1999) and Martson and Polei (2004) is also shown in Appendix B.

\section{Environmental performance}

The Political Economy Research Institute (PERI) at the University of Massachusetts Amherst identified the top 100 corporate polluters in the United States (called America's Toxic 100). In essence, the PERI's rankings constitute a measure of environmental performance as they are based on each company's toxic score. The toxic score takes into account the toxicity and the population exposure of the toxic emissions. As such, the PERI calculates the toxic score by taking the number of pounds of air releases reported in the EPA's Toxics Release Inventory, and weighs it by toxicity of chemicals and number of people impacted. Weights can be found in the EPA's RiskScreening Environmental Indicators (RSEI) project. Toxic 100 firms consisted of the top 100 companies with the highest toxic score, as provided by the PERI, and were also dichotomously categorized with a yes/no coding scheme. We assign a score of 1 if the company belongs to the Toxic 100 (worse performing firms), zero otherwise (better performing firms).

\section{Statistical analysis and results}

Multivariate analysis of covariance (MANCOVA) was conducted to determine the effect of Toxic 100 membership on both website environmental disclosure content

\footnotetext{
${ }^{14}$ There was one instance where while no content information was provided, one or more presentation feature(s) only was (were) available. Conversely, there were a few instances where no presentation feature from the evaluation metric was available, with only content information.
} 
and presentation simultaneously while controlling for firm industry (ESI versus non-ESI). MANCOVA results revealed significant differences between Toxic 100 and non-Toxic 100 firms and the combined dependent variables, Wilks' $\lambda=.583, F(2,72), \mathrm{p}<.001$, multivariate $\eta^{2}=.417$. However, the covariate (industry) did not significantly influence the combined dependent variable, Wilks' $\lambda=.951, F(2,72), \mathrm{p}=.161$, multivariate $\eta^{2}=$ .049. Analysis of covariance (ANCOVA) was conducted on each dependent variable as a follow-up test to MANCOVA. Differences between Toxic 100 and non-Toxic 100 firms were significant for both disclosure content, $\left(F(1,73)=17.142, \mathrm{p}<.001\right.$, partial $\eta^{2}=$ $.190)$ and presentation $\left(F(1,73)=47.995, \mathrm{p}<.001\right.$, partial $\left.\eta^{2}=.397\right)$. A comparison of adjusted means reveals that content and presentation score of Toxic 100 firms differs by more than 2 and 3 points, respectively, from non-Toxic 100 firms. Table 2 presents adjusted means for website environmental disclosure content and presentation scores by Toxic 100 membership.

Table 2 about here

Further t-tests of means were conducted to examine individually the statistical significance of the relations stated in each hypothesis. Table 3 presents the results of the analyses performed to test the first set of hypotheses related to website environmental disclosure content scores. $\mathrm{H}_{1 \mathrm{a}}$ focuses on differences across ESI firms and predicts higher content scores for Toxic 100 firms than their non-Toxic 100 counterparts. As panel A of Table 3 indicates, the mean disclosure content score for Toxic 100 firms is 5.11 versus a mean score of 3.47 for the non-Toxic 100 firms. The difference is significant $(\mathrm{p}<.05$, one tailed $)$ and thus supports $\mathrm{H}_{1 \mathrm{a}}$. Results of the analysis of website disclosure content score differences across non-ESI firms $\left(\mathrm{H}_{1 \mathrm{~b}}\right)$ are presented in panel B of Table 3. As shown in the table, the mean disclosure content score for Toxic 100 firms is 5.26 while the mean score for non-Toxic 100 is 2.74, and the difference is significant at $\mathrm{p}<.001$, one tailed. In contrast, $\mathrm{H}_{1 \mathrm{c}}$ predicts no difference in website disclosure content across firm industry for the Toxic 100 firms. Results presented in panel C of Table 3 support this hypothesis. The mean content score for ESI Toxic 100 firms is only slightly lower (5.11) than the mean score for non-ESI Toxic 100 firms (5.26). The difference is not statistically significant. 
The results for tests of differences in the presentation of website environmental disclosure (the second set of hypotheses) are shown in Table 4. $\mathrm{H}_{2 \mathrm{a}}$ relates to ESI firms and predicts higher presentation scores for Toxic 100 than non-Toxic 100 companies. As highlighted in panel A of Table 4, the mean disclosure presentation score for Toxic 100 firms is 6.68 compared to a mean score of 3.42 for their non-Toxic 100 counterparts. The difference is highly significant ( $\mathrm{p}=.000$, one-tailed) and thus $\mathrm{H}_{2 \mathrm{a}}$ is supported. $\mathrm{H}_{2 \mathrm{~b}}$ hypothesizes the same relation but for non-ESI firms. Test results are exhibited in panel $\mathrm{B}$ of Table 4 and indicate that the mean disclosure presentation score for Toxic 100 firms of 5.84 is significantly higher than the mean score for non-Toxic $100(2.37)$ at $p=.000$, one tailed. Finally, $\mathrm{H}_{2 \mathrm{c}}$ centers on the website disclosure presentation score for Toxic 100 firms. Similar to $\mathrm{H}_{1 \mathrm{c}}$, no difference in presentation score is expected across firm industry. Mean presentation score for Toxic 100 firms operating in ESI is 6.68 while the score for non-ESI firms is 5.84. The difference is not statistically significant and $\mathrm{H}_{2 \mathrm{c}}$ is supported.

Tables 3 and 4 about here-

\section{Discussion, limitation, and future research}

The purpose of this study was to extend organizational legitimacy arguments by examining the content and presentation of corporate website environmental disclosure in relation to firm environmental performance. We also appealed to Goffman's work to describe our expectations of firm disclosure activities relative to actual firm environmental performance. The results of the statistical analyses indicate that, on average, both the content and presentation scores of corporate website environmental disclosure were higher for worse environmental performing firms than their better counterparts. In addition, these results were shown to hold when we separately tested the disclosure content and presentation, respectively, in relation to environmental performance. However, the environmental sensitivity of firm industry did not have a significant effect on website environmental disclosure content and presentation.

Overall, these findings are consistent with the Internet legitimacy presumptions and extend the results reported by Patten and Crampton (2004). That is, poorer environmental performing firms (as defined by Toxic 100 firms) provided more extensive 
environmental disclosures in terms of content and presented their disclosures on savvier websites. This supports the argument of corporate website environmental disclosures being more concerned with legitimating corporations with negative environmental performance rather than increasing firm's environmental accountability. Internet and web technologies provide corporate public relations departments some extraordinary opportunities. While SustainAbility/UNEP highlights the potential added-value of website disclosure in its 1999 Internet Reporting Report, it also remains cautious about the availability of the Internet medium to disseminate environmental information, as it states, "unfortunately, there is a great temptation to put a public relations spin on information, whether published in a printed [environmental report] or on the website." (1999, p. 18). This especially can be pertinent to firms under the spotlight such as those ranked and labeled as America's Toxic 100. Being included on the list presumably lends to negative exposure and therefore, the "successful" management of communications and self-presentation is crucial. As Esrock and Leichty (1998) suggest, "organizations tend to communicate image building in a low key manner that may soften perceptions the organization is engaged in corporate citizenship activities only for self-serving reasons" (p. 317).

This paper is subject to a number of limitations. Restrictions related to sample criteria limited the scope of this study to a relatively small sample size, and the analysis focused on US firms only. The extent to which the results are generalizable, therefore, cannot be established. Furthermore, we examined website disclosures at a single point in time. Future research may address some of these limitations by, for example, extending the scope of this study to a wider sample of international firms across countries. Moreover, given the dynamic nature of the Internet, longitudinal analyses of corporate websites could give a more comprehensive view of the online environmental reporting motivations and practices of corporations. Finally, studies from a website/Internet user perspective (i.e., examining the perception of the user about environmental information presented in corporate websites) could also be a possible avenue for future research. 


\section{REFERENCES}

Antin, N.B. and Haas, J.D. (2001). Maintaining a corporate web site and avoiding liability under the Securities laws. Computer and Internet Lawyer, 18(6), 21-29.

Ashbaugh, H., Johnstone, K.M., and Warfield, T.D. (1999). Corporate reporting on the Internet. Accounting Horizons, 13(3), 241-257.

Azzone, G., Brophy, M., Noel, G., Welford, R., and Young, W. (1997). A stakeholder's view of environmental reporting. Long Range Planning, 30(5), 699-709.

Brown, A.D. (1997). Narcissism, identity, and legitimacy. Academy of Management Review, 22(3), 643-686.

Brown, D. K. (2003). Goffman's dramaturgical sociology: Developing a meaningful theoretical context and exercise involving "embarrassment and social organization". Teaching Sociology, 31(3), 288-299.

Cho, C.H. and Patten, D.M (2007). The role of environmental disclosures as tools of legitimacy: A research note. Accounting, Organizations and Society, 32(7-8), 639-647.

Cho, C.H., Patten, D.M., and Roberts, R.W. (2006). Corporate political strategy: An examination of the relation between political expenditures, environmental performance, and environmental disclosure. Journal of Business Ethics, 67(2), 139-154.

Debreceny, R., Gray, G.L., and Rahman, A. (2002). The determinants of Internet financial reporting. Journal of Accounting and Public Policy, 21(4/5), 371-394.

Deegan, C. (2002). The legitimizing effect of social and environmental disclosures - A theoretical foundation. Accounting, Auditing and Accountability Journal, 15(3), 282-311.

Deegan, C. and Gordon, B. (1996). A study of environmental practices of Australian corporations. Accounting and Business Research, 26(3), 187-199.

Deegan, C. and Rankin, M. (1996). Do Australian companies report environmental news objectively? An analysis of environmental disclosures by firms prosecuted successfully the Environmental Protection Authority. Accounting, Auditing and Accountability Journal, 9(2), 50-67.

Deegan, C., Rankin, M., and Tobin, J. (2002). An examination of the corporate social and environmental disclosures of BHP from 1983-1997: A test of legitimacy theory. Accounting, Auditing and Accountability Journal, 15(3), 312-343. 
Dowling, J. and Pfeffer, J. (1975). Organizational legitimacy: Social values and organizational behavior. Pacific Sociological Review, 18, 122-136.

Environmental Protection Agency. (2006). Available at $<$ http://www.epa.gov $>$.

Esrock, S.L. and Leichty,G.B. (1998). Social responsibility and corporate Web pages: Self-presentation or agenda setting? Public Relations Review, 24(3), 305-319.

Ettredge, M., Richardson, V.J., and Scholz, S. (2001). The presentation of financial information at corporate web sites. International Journal of Accounting Information Systems, 2(3), 149-168.

Flynn, G. and Gowthorpe, C. (1997). Volunteering financial data on the World Wide Web: A study of financial reporting from a stakeholder perspective. Presented at the First Financial Reporting and Business Communication Conference, Cardiff, Wales.

Foy, P. (1996). The re-invention of the corporate information model. IEEE Transactions on Professional Communications, 39(1), 23-29.

Goffman, E. (1959). The presentation of self in everyday life. New York, NY: Doubleday.

Gowthorpe, C. and Amat, O. (1999). External reporting of accounting and financial information via the Internet in Spain. European Accounting Review, 8(2), 365371.

Gray, R.H., Kouhy, R., and Lavers, S. (1995). Corporate social and environmental reporting: a review of the literature and a longitudinal study of UK disclosure. Accounting, Auditing and Accountability Journal, 8(2), 47-77.

Hackston, D. and Milne, M.J. (1996). Some determinants of social and environmental disclosures in New Zealand companies. Accounting, Auditing and Accountability Journal, 9(1), 77-108.

Hedlin, P. The Internet as a vehicle for investor relations: the Swedish case. European Accounting Review, 8(2), 373-381.

Hughes, S. B., Anderson, A., and Golden, S. (2001). Corporate environmental disclosures: are they useful in determining environmental performance? Journal of Accounting and Public Policy, 20(3), 217-240.

Ingram, R.W. and Frazier, K.B. (1980). Environmental performance and corporate disclosure. Journal of Accounting Research, 18(2), 614-622. 
Isenmann, R. and Lenz, C. (2000). Internet-based environmental reporting: System of technical benefits using the Internet for corporate environmental reports.

Proceedings of Business Strategy and the Environment Conference, University of Leeds, UK, September 2000, 203-210.

Isenmann, R. and Lenz, C. (2001). Internet-based integration of financial and environmental reporting: Step towards sustainability reporting. Proceedings of Business Strategy and the Environment Conference, University of Leeds, UK, September 2001, 169-178.

Jones, K., Alabaster, T., and Walton, J. (1998). Virtual environments for environmental reporting. Greener Management International, 21, 121-137.

Jones, K., Alabaster, T., and Hetherington, K. (1999). Internet-based environmental reporting. Greener Management International, 26, 69-90.

Konar, S. and Cohen, M.A. (1997). Information as regulation: the effect of community right to know laws in toxic emissions. Journal of Environmental Economics and Management 32(1), 109-124.

Internet World Stats. (2006). World Internet Usage Statistics and Population. Available at $<$ http://www.internetworldstats.com/stats.htm $>$.

Lindbolm, C.K. (1994). The implications of organizational legitimacy for corporate social performance and disclosure. Paper presented at the Critical Perspectives on Accounting Conference, New York, NY.

Marston, C. and Polei, A. (2004). Corporate reporting on the Internet by German companies. International Journal of Accounting Information Systems, 5(3), 285 311.

Matthews, M.R. (1993). Socially Responsible Accounting. London: Chapman and Hall.

Milne, M.J. and Adler, R.W. (1999). Exploring the reliability of social and environmental disclosures content analysis. Accounting, Auditing and Accountability Journal, 12(2), 237-256.

Milne, M.J. and Patten, D.M. (2002). Securing organizational legitimacy: An experimental decision case examining the impact of environmental disclosures. Accounting, Auditing and Accountability Journal, 15(3), 372-405.

Neu, D., Warsame, H., and Pedwell, K. (1998). Managing public impressions: environmental disclosures in annual reports. Accounting, Organizations and Society, 23(3), 265-82. 
O’Donovan, G. (1999). Managing legitimacy through increased corporate environmental reporting: An exploratory study. Interdisciplinary Environmental Review, 1(1), 63-99.

O'Donovan, G. (2002). Environmental disclosures in the annual report: Extending the applicability and predictive power of legitimacy theory. Accounting, Auditing and Accountability Journal, 15(3), 344-371.

Patten, D.M. (1991). Exposure, legitimacy, and social disclosure. Journal of Accounting and Public Policy, 10(4), 297-308.

Patten, D.M. (1992). Intra-industry environmental disclosures in response to the Alaskan oil spill: A note on legitimacy theory. Accounting, Organizations and Society, $17(5), 471-475$.

Patten, D.M. (1995). Variability in social disclosure: A legitimacy-based analysis. Advances in Public Interest Accounting, 6, 273-285.

Patten, D.M. (2002a). The relation between environmental performance and environmental disclosure: a research note. Accounting, Organizations and Society, 27(8), 763-773.

Patten, D.M. (2002b). Give or take on the Internet: An examination of the disclosure practices of insurance firm web innovators. Journal of Business Ethics, 36(3), 247-259.

Patten, D.M. and Crampton, W. (2004). Legitimacy and the Internet: An examination of corporate web page environmental disclosures. Advances in Environmental Accounting and Management, 2, 31-57.

Rauch, T., Leone, P., and Gillhan, D. (1997). Enabling the book metaphor for the World Wide Web: Disseminating on-line information as dynamic web documents. IEEE Transactions on Professional Communications, 40(2), 16-22.

Roberts, R.W. (1992). Determinants of corporate social responsibility disclosure: An application of stakeholder theory. Accounting, Organizations and Society, 17(6), 595-612.

Shepherd, K., Abkowitz, M., and Cohen, M.A. (2001). Online corporate environmental reporting: Improvements and innovation to enhance stakeholder value. Corporate Environmental Strategy, 8(4), 307-315.

Shocker, A. and Sethi, S. (1973). An approach to incorporating societal preferences in developing corporate action strategies. California Management Review, 97-105. 
Smith, M. A. (2000). American Business and Political Power. Chicago, IL: The University of Chicago Press.

SustainAbility/UNEP. (1999). The Internet Reporting Report. London: The Beacon Press.

Unerman, J. (2000). Reflections on quantification in corporate social reporting content analysis. Accounting, Auditing and Accountability Journal, 13(5), 667-680.

Weber, M. (1966). The Theory of Social and Economic Organization. New York, NY: Free Press.

Wheeler, D. and Elkington, J. (2001). The end of the corporate environmental report? On the advent of cybernetic sustainability reporting and communication. Business Strategy and the Environment, 10, 1-14.

Williams, S.M and Pei, C.A.H.W. (1999). Corporate social disclosures by listed companies on their web sites: An international comparison. The International Journal of Accounting, 34(3), 389-419.

Wolf, S.M. (1996). Fear and loathing about the public right to know: The surprising success of the Emergency Planning and Community Right-to-Know Act. Journal of Land Use and Environmental Law, 11(2), 217-234.

Young, T.R. and Massey, G. (1978). The dramaturgical society: A macro-analytic approach to dramaturgical analysis. Qualitative Sociology, 1(2), 78-98.

Zeghal, D. and Ahmed, S.A. (1990). Comparison of social responsibility information disclosure media used by Canadian firms. Accounting, Auditing and Accountability Journal, 3(1), 38-53. 
Table 1

Descriptive statistics

$n$ (sample size)

76

Firm size (2005 revenues)

Mean

$\$ 7,651.3$ million

Median

$6,329.7$ million

Standard deviation

4,794.3 million

Environmental disclosure content analysis score $(\max =21)$

Mean

4.14

Standard deviation

Environmental disclosure presentation analysis score $(\max =20)$

Mean

4.58

Standard deviation

2.73 
Table 2

Adjusted means for corporate environmental disclosure content and presentation scores by Toxic 100 membership

Website disclosure presentation score

\section{Adjusted mean}

Toxic 100 firms

5.184

Non-Toxic 100 firms

3.105

Website disclosure content score

Toxic 100 firms

6.263

Non-Toxic 100 firms

2.895 
Table 3

Results of t-tests of mean website environmental disclosure presentation disclosure scores

\section{Panel A}

ESI companies

\begin{tabular}{|c|c|c|}
\hline $\begin{array}{l}\text { Mean } \\
\text { score }\end{array}$ & $\begin{array}{l}\text { Standard } \\
\text { deviation }\end{array}$ & $t$-statistic \\
\hline
\end{tabular}

Toxic 100 firms

$6.68 \quad 1.916$

Non-Toxic 100 firms

$3.42 \quad 1.710$

5.538

.000

\section{Panel B}

\section{Non-ESI companies}

$\begin{array}{lll}\text { Mean } & \begin{array}{l}\text { Standard } \\ \text { deviation }\end{array} \quad t \text {-statistic } & \begin{array}{l}\text { Statistical } \\ \text { significance* }\end{array}\end{array}$

Toxic 100 firms

$5.84 \quad 2.968$

Non-Toxic 100 firms

$2.37 \quad 1.674$

4.444

.000

\section{Panel C}

Toxic 100 firms

$\begin{array}{llll}\text { Mean } & \begin{array}{l}\text { Standard } \\ \text { deviation }\end{array} & t \text {-statistic } & \begin{array}{l}\text { Statistical } \\ \text { significance* }\end{array}\end{array}$

ESI firms

$6.68 \quad 1.92$
5.84

Non-ESI firms

$5.84 \quad 2.97$

1.039

.153

* Significance levels are one-tailed. 
Table 4

Results of t-tests of mean website environmental disclosure content disclosure scores

\section{Panel A}

ESI companies

\begin{tabular}{|c|c|}
\hline $\begin{array}{l}\text { Mean } \\
\text { score }\end{array}$ & $\begin{array}{l}\text { Standard } \\
\text { deviation }\end{array}$ \\
\hline
\end{tabular}

Toxic 100 firms

$5.11 \quad 2.307$

Non-Toxic 100 firms

$3.47 \quad 2.270$

2.198

$<.05$

\section{Panel B}

\section{Non-ESI companies}

\begin{tabular}{|c|c|c|}
\hline $\begin{array}{l}\text { Mean } \\
\text { score }\end{array}$ & $\begin{array}{l}\text { Standard } \\
\text { deviation }\end{array}$ & $t$-statistic \\
\hline
\end{tabular}

Toxic 100 firms

$5.26 \quad 2.513$

Non-Toxic 100 firms

$2.74 \quad 1.538$

3.724

.000

\section{Panel C}

Toxic 100 firms

$\begin{array}{lll}\text { Mean } & \begin{array}{l}\text { Standard } \\ \text { deviation }\end{array} & t \text {-statistic }\end{array} \quad \begin{aligned} & \text { Statistical } \\ & \text { significance* }\end{aligned}$

ESI firms $\quad 5.11 \quad 2.51$

$\begin{array}{lllll}\text { Non-ESI firms } & 5.26 & 2.31 & 0.202 & .425\end{array}$

* Significance levels are one-tailed 


\section{Appendix A}

\section{SustainAbility/UNEP's 5-stage reporting model*}

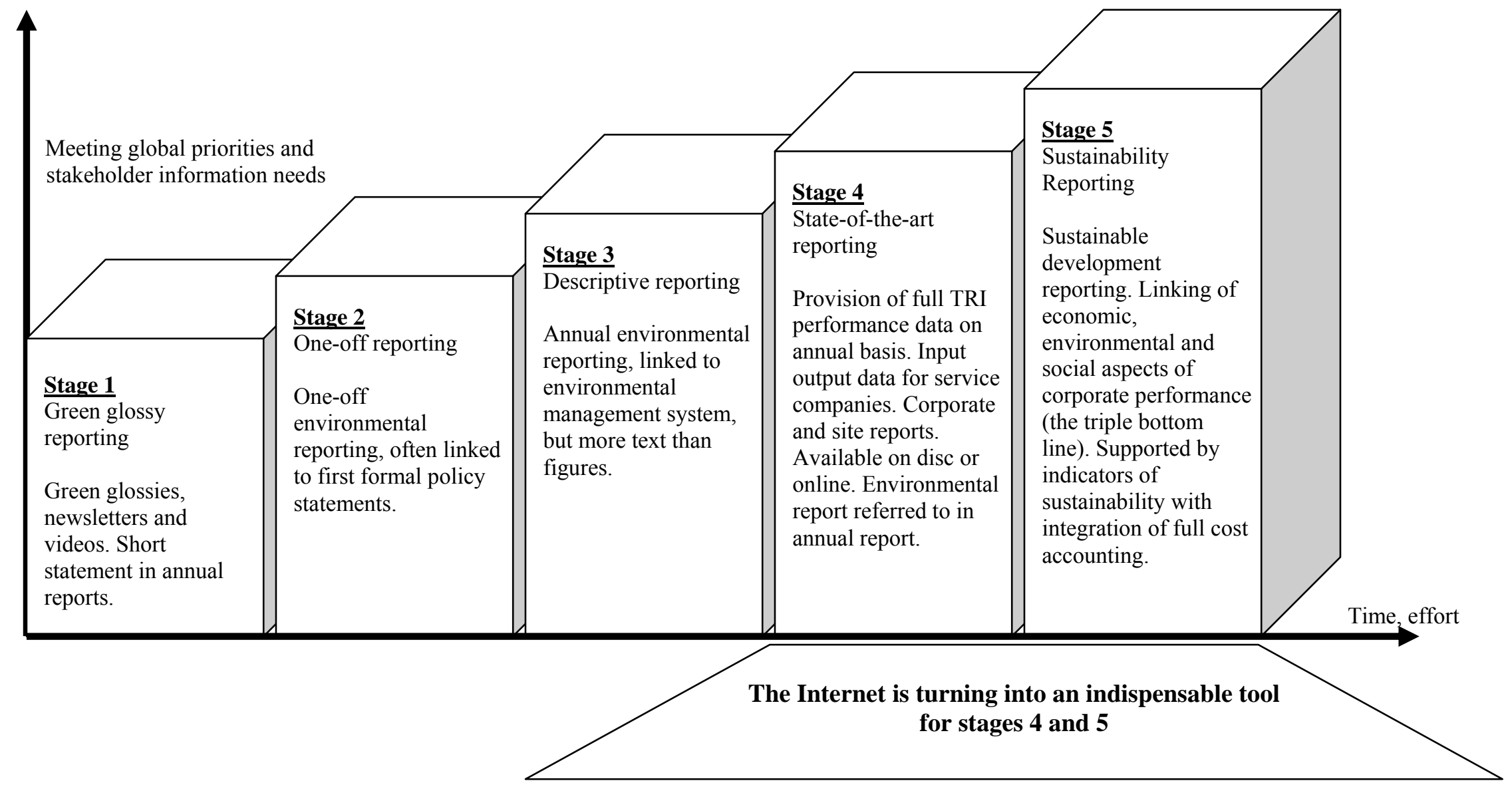

Adapted from SustainAbility/UNEP (1999) and Isenmann and Lenz (2001). 


\section{Appendix B}

\section{Comprehensive environmental disclosure evaluation metric}

\section{WEBSITE ENVIRONMENTAL DISCLOSURE CONTENT*}

\section{Economic}

1. Current or past capital expenditures for pollution abatement or control

2. Current or past operating costs for pollution abatement or control

3. Projection of future expenditures for pollution abatement or control

4. Projection of future operating costs for pollution abatement or control

\section{Pollution Abatement}

5. Air emission/TRI information is provided

6. Water discharge information is provided

7. Solid waste disposal information is provided

8. Pollution control or abatement facilities or processes are discussed

9. Compliance status is mentioned or discussed

\section{Other Disclosures}

10. Discussion or mention of environmental regulations or requirements

11. Statement of environmental policies or company concern for the environment

12. Conservation of natural resources is discussed

13. Mention or discussion of environmental awards

14. Recycling information/issues are discussed

15. Disclosure of an office or department for environmental control

16. Discussion of environmental attributes of products

17. Discussion of environmental audit activities

18. Discussion of exposures due to past or present remediation problems

19. Specific disclosure that the company has been named as a potentially responsible party

20. Discussion and/or disclosure of monetary accruals and/or expenses (or their existence) incurred for remediation

21. Discussion of exposures due to other, non remediation-related environmental problems

* All items (1 to 21) were reproduced from Patten and Crampton (2004). 
Comprehensive environmental disclosure evaluation metric* (continued)

\section{WEBSITE ENVIRONMENTAL DISCLOSURE PRESENTATION}

\section{Technological features}

1. Environmental report in Hypertext Markup Language (HTML) format ${ }^{\mathrm{a}, \mathrm{b}}$

2. Environmental report in Portable Document Format (PDF) ${ }^{\mathrm{a}, \mathrm{b}}$

3. Feedback/order forms ${ }^{\mathrm{a}}$

4. Additional environmental documents available in PDF or other formats ${ }^{\mathrm{a}}$

5. Hyperlinks inside the environmental report ${ }^{\mathrm{b}}$

\section{Interactive and multimedia environmental information}

6. Graphic images (pictures, charts) ${ }^{\mathrm{a}, \mathrm{b}}$

7. Flashes ${ }^{\mathrm{b}}$

8. Audio/Sound files or clips ${ }^{\mathrm{b}}$

9. Video files or clips ${ }^{\mathrm{b}}$

10. Interactive adventure stories/games ${ }^{\mathrm{a}}$

\section{Structure and navigation (environmental section of website)}

\section{Page divided into frames ${ }^{b}$}

12. Transparent link on main home page to get to environmental information ${ }^{\mathrm{c}}$

13. Number of clicks to get to environmental information $<1$ (encoded zero if more) ${ }^{b}$

14. Pull-down or click-over menu ${ }^{\mathrm{b}}$

15. Next/previous buttons to navigate sequentially ${ }^{b}$

16. Internal hyperlinks ${ }^{\mathrm{a}}$

17. External hyperlinks ${ }^{\mathrm{a}}$

\section{Convenience and usability of website}

18. Change to printing friendly format possible ${ }^{b}$

19. Function to recommend the page ${ }^{\mathrm{b}}$

20. Direct e-mail hyperlink or contact details of environmental team ${ }^{\mathrm{a}, \mathrm{b}}$

${ }^{a}$ Item was adapted from Jones et al. (1998)

${ }^{\mathrm{b}}$ Item was adapted from Marston and Polei (2004)

${ }^{\mathrm{c}}$ Item was created as a variation based on item \# 13

* This report can also be called the Environmental Statement, Citizenship Report, the Sustainability Report, the Health, Safety and Environmental Report or the Corporate Social Responsibility Report. All these reports are integrative of environmental information provided by companies. 


\section{List of omitted items from sources}

\begin{tabular}{|c|c|c|}
\hline Item & Source & Reason for exclusion \\
\hline $\begin{array}{l}\text { Loading time of the website } \\
<10 \text { seconds }\end{array}$ & Marston and Polei (2004) & $\begin{array}{l}\text { Feature was present for all examined } \\
\text { websites }\end{array}$ \\
\hline $\begin{array}{l}\text { Text only alternative } \\
\text { available }\end{array}$ & Marston and Polei (2004) & $\begin{array}{l}\text { Feature was absent for all examined } \\
\text { websites }\end{array}$ \\
\hline $\begin{array}{l}\text { Financial data in } \\
\text { processable format }\end{array}$ & Marston and Polei (2004) & $\begin{array}{l}\text { Feature was not applicable to } \\
\text { environmental website disclosure }\end{array}$ \\
\hline Help site & Marston and Polei (2004) & $\begin{array}{l}\text { Feature was not relevant specifically to } \\
\text { environmental website disclosure }\end{array}$ \\
\hline Table of content/site map & Marston and Polei (2004) & $\begin{array}{l}\text { Feature was not relevant specifically to } \\
\text { environmental website disclosure }\end{array}$ \\
\hline Internal search engine & Marston and Polei (2004) & $\begin{array}{l}\text { Feature was not relevant specifically to } \\
\text { environmental website disclosure }\end{array}$ \\
\hline $\begin{array}{l}\text { Online investor information } \\
\text { order service }\end{array}$ & Marston and Polei (2004) & $\begin{array}{l}\text { Feature was not applicable to } \\
\text { environmental website disclosure }\end{array}$ \\
\hline Mailing list & Marston and Polei (2004) & $\begin{array}{l}\text { Feature was absent for all examined } \\
\text { websites }\end{array}$ \\
\hline $\begin{array}{l}\text { Number of clicks to get to } \\
\text { press releases or news }\end{array}$ & Marston and Polei (2004) & $\begin{array}{l}\text { Feature was not applicable to } \\
\text { environmental website disclosure }\end{array}$ \\
\hline $\begin{array}{l}\text { Clear boundaries between } \\
\text { the annual report (audited) } \\
\text { and other information }\end{array}$ & Marston and Polei (2004) & $\begin{array}{l}\text { Feature was not applicable to } \\
\text { environmental website disclosure }\end{array}$ \\
\hline $\begin{array}{l}\text { Service to change data in } \\
\text { the Share register online }\end{array}$ & Marston and Polei (2004) & $\begin{array}{l}\text { Feature was not applicable to } \\
\text { environmental website disclosure }\end{array}$ \\
\hline Environmental education & Jones et al. (1999) & $\begin{array}{l}\text { Feature was absent for all examined } \\
\text { websites }\end{array}$ \\
\hline Environmental forums & Jones et al. (1999) & $\begin{array}{l}\text { Feature was absent for all examined } \\
\text { websites }\end{array}$ \\
\hline Site design & Jones et al. (1999) & $\begin{array}{l}\text { Feature was captured by other } \\
\text { individual items included in the metric }\end{array}$ \\
\hline Navigation & Jones et al. (1999) & $\begin{array}{l}\text { Feature was captured by other } \\
\text { individual items included in the metric }\end{array}$ \\
\hline Regular updates & Jones et al. (1999) & $\begin{array}{l}\text { Feature was captured by the } \\
\text { external/internal hyperlinks items }\end{array}$ \\
\hline Site promotion & Jones et al. (1999) & $\begin{array}{l}\text { Based on its definition, feature was not } \\
\text { applicable to this research }\end{array}$ \\
\hline
\end{tabular}

